\title{
What can long-term range reference areas tell us?
}

\author{
Here's an analysis of fifty years of plant succession \\ in the Rocky Mountain Trench
}

\author{
By Timothy J. Ross and Brian M. Wikeem
}

$\mathrm{G}$ rassland and forest range provide forage and habitat for cattle, horses, elk, whitetail deer, and mule deer in the Rocky Mountain Trench of southeastern British Columbia (BC). Historically, these rangelands evolved and were modified by a number of factors including climate, soils, fire, forest encroachment, logging, land alienation, and grazing by domestic livestock and wildlife.

A series of wildlife, soil, and range surveys between 1953 and 1956 concluded that grasslands in the Trench were overgrazed and carrying capacity for wildlife and livestock was below its capacity. As a result, conflicts emerged during the 1960s and 1970s concerning dietary overlap and forage allocation among cattle, elk, whitetail deer, and mule deer.

In addition to historical influences, three important, and interacting factors, have dominated resource management in the East Kootenay since the 1960s: forest ingrowth, potential competition between native ungulates and domestic livestock, and deterioration of range condition.

\section{Forest Ingrowth}

Forest encroachment onto grassland was recognized as a problem of provincial scope as early as 1918. In 1950, Dr. Ed Tisdale reported that "invasion of open or lightly timbered ranges by forest growth ....is a significant problem affecting forest range carrying capacity...[and] the invasion of open or semi-open areas by tree growth, with consequent reductions in grazing capacity and usefulness as early range is a common phenomenon over much of the interior.... it seems to be mainly a natural return of trees to areas deforested in the past by repeated fires."

Tisdale's comments appear prophetic in that forest succession in the Trench has been inexorable since the fires from 1914-1931 and open range for wild and domestic herbivores has declined dramatically.

\section{Wildlife/Livestock Interactions}

Coordinated Resource Management Planning (CRMP) was introduced into BC and the East Kootenay in 1975, primarily to resolve cattle-elk conflicts. Indeed, the need for a consultative process to allocate forage, and to ensure the long-term sustainability of the range resource, was a central issue in the East Kootenay.

Coordinated Resource Management improved forage availability, forage quality, and productivity for wild ungulates and domestic livestock in the East Kootenay. Between 1982 and 1991, however, the elk population in the Trench increased from nearly 10,000 to more than 25,000 animals while cattle AUMs remained relatively constant.

In 1982, Dr. M. Pitt reported that many resource managers believed increased grazing pressure, combined with forest ingrowth and land alienation, continued to produce downward trends in range condition. Wildlife supporters argued that high cattle stocking rates, and improper seasons of use, had altered species composition in plant communities and reduced forage production capability.

Conversely, ranching advocates maintained that grazing programs implemented under CRMP were responsible for the initial improvements in range productivity, and that overgrazing likely resulted from wildlife populations using low-elevation rangelands when cattle were not present.

The East Kootenay Trench Agriculture/Wildlife Committee was formed in 1990 to address resource management issues in the Trench through improved inventory and monitoring of the wildlife and range resources, better public education, and through habitat and range enhancement. Among the many projects proposed, it was generally agreed that re-sampling the historical range reference exclosure on Skookumchuck Prairie could provide valuable information regarding range recovery in the Trench.

\section{Past, Present \& Future Natural Communities}

The Skookumchuck exclosure is located in the Rocky Mountain Trench about $60 \mathrm{~km}$ north of Cranbrook, B.C. The area is an important winter range for deer and elk, and has been grazed by livestock for over 100 years. Skookumchuck Prairie occurs in the Ponderosa Pine biogeoclimatic zone at about $780 \mathrm{~m}$ elevation and soils in the area are classified as Orthic Eutric Brunisols (Typic 


\begin{tabular}{|c|c|}
\hline \multicolumn{2}{|c|}{$\begin{array}{l}\text { Common and Scientific Names from } \\
\text { Skookumchuck Prairie Exclosure }\end{array}$} \\
\hline Common Name & Scientific Name \\
\hline \multicolumn{2}{|l|}{ Grasses } \\
\hline Bluebunch wheatgrass & Agropyron spicatum \\
\hline Idaho fescue & Festuca idahoensis \\
\hline Kentucky bluegrass & Poapratensis \\
\hline Needle-and-thread & Stipa comata \\
\hline Pinegrass & Calamagrostis rubescens \\
\hline Prairie Junegrass & Koeleria cristata \\
\hline Rough fescue & Festuca scabrella \\
\hline Sandberg's bluegrass & Poa secunda \\
\hline \multicolumn{2}{|l|}{ Forbs } \\
\hline Brown-eyed susan & Gaillardia aristata \\
\hline Dandelion & Taraxicum officinale \\
\hline Death camas & Zygadenus venenosus \\
\hline Dune goldenrod & Solidago spathulata \\
\hline Dwarf mountain fleabane & Erigeron compositus \\
\hline Early blue violet & Viola adumca \\
\hline Fairy candelabra & Androsace septentrionalis \\
\hline Goatsbeard & Tragopogon pratense \\
\hline Hairy goldaster & Crysopsis villosa \\
\hline Holboell's rockcress & Arabis holboellii \\
\hline Large-fruited lomatium & Lomatium macrocarpum \\
\hline Low pussytoes & Antennaria dimorpha \\
\hline Nine-leaf lomatium & Lomatium triternatum \\
\hline Nodding onion & Allium cermuam \\
\hline Old man's whiskers & Geum triflorum \\
\hline Pacific anemone & Anemone patens \\
\hline Prairie groundsel & Senecio camus \\
\hline Rosy pussytoes & Antennaria microphylla \\
\hline Sagebrush mariposa lily & Calochortus macrocarpus \\
\hline Shaggy fleabane & Erigeron pumilus \\
\hline Shooting star & Dodecatheon pauciflorum \\
\hline Slender hawksbeard & Crepis atrabarba \\
\hline Spiny phlox & Phlox caespitosa \\
\hline Sulphur buckwheat & Eriogomum umbellatum \\
\hline Sulphur cinquefoil & Potentilla recta \\
\hline Thin-leaved owlclover & Orthocarpus temufolium \\
\hline Timber milkvetch & Astragalus miser \\
\hline Western yarrow & Achillea millefolium \\
\hline Wyeth buckwheat & Eriogomum heracleoides \\
\hline Yellow buckwheat & Eriogonum flavum \\
\hline Yellow owlclover & Orthocarpus luteus \\
\hline \multicolumn{2}{|l|}{ Trees and Shrubs } \\
\hline Bearberty & Arctostaphyalus uva-ursa \\
\hline Douglas-fir & Pseudotsuga menziesii \\
\hline Ponderosa pine & Pimus ponderosa \\
\hline
\end{tabular}

Eutrochrept) or Orthic Dark Brown Chernozems (Typic Boroll). Normal mean annual precipitation is about 370 $\mathrm{mm}$ and August $\left(32.2^{\circ} \mathrm{C}\right)$ and January $\left(-26.3^{\circ} \mathrm{C}\right)$ are the hottest and coldest months, respectively.

Built in 1951, Skookumchuck exclosure is the oldest maintained reference area in the Trench. It was established to compare long-term floristic changes resulting from the exclusion of elk, deer, and cattle with an adjacent grazed area. No baseline data were collected in 1951, but in 1972, Dr. A. McLean described the original plant community as being dominated by Sandberg's bluegrass, prairie Junegrass, needle-and-thread and low pussytoes. The first cover and frequency data were collected in 1960 and at approximately ten-year intervals thereafter.

\section{Successional Patterns In The Grazed Area}

In 1960 very little had changed on the site since McLean's first observations in 1951. Grass cover was nearly $55 \%$ while forbs provided about $35 \%$ cover in the grazed area (Table 1). Sandberg's bluegrass, prairie Junegrass, bluebunch wheatgrass, and needle-and-thread were still the dominant grasses, and low pussytoes was the dominant forb comprising $>25 \%$ canopy cover. All other forbs contributed $<2 \%$ cover and no trees or shrubs were present on the site (Table 1). Dominant species for the Ponderosa Pine zone, such as ponderosa pine and Idaho fescue, were absent in the grazed area while rough fescue accounted for only $6 \%$ cover.

Although several plant species varied in cover and frequency among sampling periods, the composition of the grazed plant community in 1994 was strikingly similar to the original communities described in 1951 and sampled in 1960. Bluebunch wheatgrass and prairie Junegrass initially increased in cover and frequency peaking in 1970 and 1982. By 1994, however, cover and frequency of both species had declined to nearly the same values as in 1960 (Table 1).

Sandberg's bluegrass, which was the dominant grass in 1960, declined to <1\% cover and 2\% frequency in 1994 . In contrast, needle-and-thread increased from slightly $>4 \%$ cover in 1960 to become the dominant grass $(>25 \%$ cover) in 1994 replacing Sandberg's bluegrass (Table 1). Rough fescue, Idaho fescue, and ponderosa pine were all recorded on the grazed area between 1982 and 1991 but they remained minor components of the community after more than 50 years.

\section{Successional Patterns Inside The Exclosure}

In contrast to the grazed area, species composition changed in almost every sampling interval in the exclosure (Table 2). In 1972, Dr. A. McLean and Dr. E. Tisdale concluded that the plant community had advanced from poor to fair condition between 1951 and 1960 , and to excellent condition by 1970 . They also reported improvements in the grazed area, which had received heavy spring and fall livestock grazing for many years. In 1950, the grazing management was altered to reduce the stocking rate and delay spring turnout.

Successional trends inside the exclosure followed patterns that would be expected with protection from grazing. Prairie Junegrass, Sandberg's bluegrass and needle-andthread, which were co-dominants with bluebunch wheatgrass in 1960, all declined over the 50 years (Table 2).

Bluebunch wheatgrass followed a similar, but less pronounced, trend. Although cover nearly doubled from 1960 to 1970 , it had declined to about $33 \%$ of its original value by 1994 (Table 2). In addition, cover and frequency of bluebunch wheatgrass was similar to the grazed area in 1994 (Table 1,2) suggesting that the presence or absence of grazing was not the only factor af- 
Table 1. Percent cover and frequency of plant species at Skookumchuck Prairie exclosure, grazed area, $1960-1994$.

\begin{tabular}{|c|c|c|c|c|c|c|c|c|c|c|}
\hline \multirow[b]{2}{*}{ Species } & \multicolumn{2}{|c|}{1960} & \multicolumn{2}{|c|}{1970} & \multicolumn{2}{|c|}{1982} & \multicolumn{2}{|c|}{1991} & \multicolumn{2}{|c|}{1994} \\
\hline & Cover & Freq & Cover & Freq & Cover & $\overline{\text { Freq }}$ & $\overline{\text { Cover }}$ & Freq & Cover & Freq \\
\hline \multicolumn{11}{|l|}{ Grasses } \\
\hline Bluebunch wheatgrass & 6.8 & 26.0 & 13.0 & 62.0 & 14.0 & 54.0 & 7.6 & 44.0 & 6.4 & 36.0 \\
\hline Idaho fescue & 0.0 & 0.0 & 0.0 & 0.0 & 0.0 & 0.0 & 0.5 & 20.0 & 0.1 & 2.0 \\
\hline Rough fescue & 0.0 & 0.0 & $\mathrm{~T}$ & 2.0 & $T$ & 2.0 & 0.9 & 8.0 & 1.0 & 4.0 \\
\hline Prairie Junegrass & 16.6 & 90.0 & 20.0 & 94.0 & 5.0 & 66.0 & 0.9 & 24.0 & 14.0 & 92.0 \\
\hline Kentucky bluegrass & 0.0 & 0.0 & 0.0 & 0.0 & 0.0 & 0.0 & 0.2 & 0.6 & 0.9 & 6.0 \\
\hline Sandberg's bluegrass & 26.2 & 98.0 & 10.0 & 94.0 & 0.0 & 0.0 & 0.4 & 0.6 & 0.1 & 2.0 \\
\hline Needle-and-thread & 4.2 & 68.0 & 34.0 & 98.0 & 47.0 & 100.0 & 13.9 & 100.0 & 25.8 & 96.0 \\
\hline Total Grasses & 53.8 & & 77.0 & & 66.0 & & 24.4 & & 48.3 & \\
\hline \multicolumn{11}{|l|}{ Forbs } \\
\hline Brown-eyed susan & 0.0 & 0.0 & 0.0 & 0.0 & 1.0 & 16.0 & 0.0 & 0.0 & 1.4 & 16.0 \\
\hline Dandelion & 0.0 & 0.0 & 1.0 & 20.0 & $T$ & 4.0 & 0.0 & 0.0 & 0.3 & 12.0 \\
\hline Death camas & 0.0 & 0.0 & 0.0 & 0.0 & $T$ & 2.0 & 0.2 & 8.0 & 0.2 & 8.0 \\
\hline Dune goldenrod & 1.2 & 20.0 & 0.0 & 0.0 & 0.0 & 0.0 & 0.0 & 0.0 & 0.0 & 0.0 \\
\hline Goatsbeard & 0.0 & 0.0 & $T$ & 2.0 & $T$ & 4.0 & 0.0 & 0.0 & 0.6 & 6.0 \\
\hline Hairy goldaster & 0.0 & 0.0 & 0.0 & 0.0 & $\mathrm{~T}$ & 2.0 & 0.0 & 0.0 & 0.1 & 2.0 \\
\hline Holboell's rockcress & 1.3 & 14.0 & $T$ & 14.0 & $\mathrm{~T}$ & 18.0 & 0.0 & 0.0 & 0.3 & 12.0 \\
\hline Large-fruited lomatium & 0.3 & 2.0 & 0.0 & 0.0 & 0.0 & 0.0 & 0.0 & 0.0 & 0.0 & 0.0 \\
\hline Low pussytoes & 26.4 & 98.0 & 8.0 & 58.0 & $T$ & 2.0 & 0.6 & 16.0 & 0.8 & 4.0 \\
\hline Nodding onion & 0.1 & 2.0 & 0.0 & 0.0 & $\mathrm{~T}$ & 2.0 & 0.0 & 0.0 & 0.1 & 2.0 \\
\hline Pacific anemone & 0.0 & 0.0 & 0.0 & 0.0 & 0.0 & 0.0 & 0.1 & 2.0 & 0.0 & 0.0 \\
\hline Prairie groundsel & 0.0 & 0.0 & 0.0 & 0.0 & 2.0 & 34.0 & 1.9 & 44.0 & 6.9 & 60.0 \\
\hline Rosy pussytoes & 1.3 & 6.0 & 9.0 & 34.0 & 4.0 & 58.0 & 3.0 & 50.0 & 4.6 & 54.0 \\
\hline Sagebrush mariposa lily & 0.0 & 0.0 & 0.0 & 0.0 & $\mathrm{~T}$ & 2.0 & 0.0 & 0.0 & 0.1 & 2.0 \\
\hline Shaggy fleabane & 1.2 & 30.0 & 4.0 & 54.0 & 4.0 & 90.0 & 0.2 & 8.0 & 1.9 & 24.0 \\
\hline Shooting star & 0.0 & 0.0 & 0.0 & 0.0 & 0.0 & 0.0 & 0.0 & 0.0 & 0.1 & 2.0 \\
\hline Spiny phlox & 1.1 & 14.0 & 3.0 & 22.0 & 2.0 & 40.0 & 3.1 & 46.0 & 6.7 & 50.0 \\
\hline Sulphur buckwheat & 1.4 & 38.0 & 2.0 & 22.0 & $T$ & 2.0 & 0.1 & 2.0 & 0.3 & 2.0 \\
\hline Sulphur cinquefoil & 0.0 & 0.0 & 0.0 & 0.0 & 0.0 & 0.0 & 1.3 & 22.0 & 2.0 & 30.0 \\
\hline Thin-leaved owlclover & 0.0 & 0.0 & 0.0 & 0.0 & $T$ & 2.0 & 0.0 & 0.0 & 0.0 & 0.0 \\
\hline Timber milkvetch & 0.0 & 0.0 & 0.0 & 0.0 & 1.0 & 18.0 & 0.6 & 4.0 & 1.6 & 16.0 \\
\hline Westem yarrow & 0.4 & 6.0 & 0.0 & 0.0 & 2.0 & 14.0 & 0.1 & 2.0 & 2.2 & 18.0 \\
\hline Yellow owlclover & 0.0 & 0.0 & 0.0 & 0.0 & 0.0 & 0.0 & 1.2 & 48.0 & 0.0 & 0.0 \\
\hline Other Forbs & 1.6 & & 1.0 & & 1.0 & & 1.5 & & 3.0 & \\
\hline Total Forbs & 36.3 & & 28.0 & & 17.0 & & 13.9 & & 33.2 & \\
\hline \multicolumn{11}{|l|}{ Trees and Shrubs } \\
\hline Ponderosa pine & 0.0 & 0.0 & 0.0 & 0.0 & $T$ & 2.0 & 0.1 & 2.0 & 0.9 & 6.0 \\
\hline Total Trees and Shrubs & 0.0 & & 0.0 & & $\mathrm{~T}$ & & 0.1 & & 0.9 & \\
\hline
\end{tabular}

fecting its position in the plant community.

Although the site was considered to be in excellent range condition in 1982, further changes have occurred in the plant community up to 1994 . Bluebunch wheatgrass, for example, has been largely replaced by rough fescue and Idaho fescue between 1982 and 1994 (Table 2). Indeed, Idaho fescue has increased to $25 \%$ cover over this period (Table 2). In contrast, rough fescue cover has decreased and it appears likely that eventually it will be replaced by Idaho fescue.

The number of forbs present in the exclosure increased from 7 species in 1960 to 19 in 1994. Similarly, forb cover nearly tripled over the same time (Table 2). Low pussytoes, which dominated forb cover in 1960, declined to $<1 \%$ cover by 1994 . Meanwhile, rosy pussytoes, spiny phlox, and western yarrow increased to provide over $20 \%$ cover collectively. All other forbs contributed $<3 \%$ cover in 1994 (Table 2). Further protection from grazing is unlikely to result in further forb cover in the exclosure.
Other than ponderosa pine, shrubs and trees were a minor component of the flora inside the exclosure, even after 50 years of protection from grazing. In fact, bearberry was the only shrub to immigrate into the exclosure up to 1970 but it disappeared from the site by 1994 (Table 2).

Recruitment of ponderosa pine seedlings occurred slowly inside the exclosure even though a few scattered trees were present in 1951 . This species was not present in 1982 and only provided $2.5 \%$ cover 40 years after the exclosure was constructed. By 1994 ponderosa pine cover had quintupled from 1991 and further changes in the understory vegetation can be expected (Table 2). The absence of fire in the region likely contributed to the establishment and survival of ponderosa pine although increased litter cover provides slightly more mesic conditions for seeds to germinate and establish.

In 1968, Dr. A McLean and Mr. L. Marchand concluded that bluebunch wheatgrass was the dominant understory species with rough fescue and Idaho fescue as 
Table 2. Percent cover and frequency of plant species at Skookumchuck Prairie exclosure, ungrazed area, 1960-1994.

\begin{tabular}{|c|c|c|c|c|c|c|c|c|c|c|}
\hline \multirow[b]{2}{*}{ Species } & \multicolumn{2}{|c|}{1960} & \multicolumn{2}{|c|}{1970} & \multicolumn{2}{|c|}{1982} & \multicolumn{2}{|c|}{1991} & \multicolumn{2}{|c|}{1994} \\
\hline & Cover & Freq & $\overline{\text { Cover }}$ & Freq & Cover & Freq & Cover & Freq & Cover & Freq \\
\hline \multicolumn{11}{|l|}{ Grasses } \\
\hline Bluebunch wheatgrass & 24.7 & 72.0 & 55.0 & 96.0 & 12.7 & 68.0 & 5.4 & 52.0 & 8.1 & 42.0 \\
\hline Idaho fescue & 0.0 & 0.0 & 0.0 & 0.0 & 1.0 & 18.0 & 7.9 & 80.0 & 25.0 & 84.0 \\
\hline Rough fescue & 6.0 & 36.0 & 20.0 & 48.0 & 58.8 & 98.0 & 23.8 & 94.0 & 32.3 & 80.0 \\
\hline Prairie Junegrass & 23.4 & 94.0 & 9.0 & 72.0 & 4.2 & 58.0 & 1.0 & 20.0 & 4.7 & 32.0 \\
\hline Sandberg's bluegrass & 17.5 & 100.0 & 5.0 & 50.0 & 0.1 & 4.0 & 0.3 & 12.0 & 0.1 & 4.0 \\
\hline Needle-and-thread & 16.7 & 74.0 & 1.0 & 4.0 & 0.0 & 0.0 & 0.0 & 0.0 & 0.0 & 0.0 \\
\hline Total Grasses & 88.3 & & 90.0 & & 76.8 & & 38.4 & & 70.2 & \\
\hline \multicolumn{11}{|l|}{ Forbs } \\
\hline Fairy candelabra & 0.0 & 0.0 & 0.0 & 0.0 & 0.0 & 0.0 & 0.1 & 2.0 & 0.6 & 6.0 \\
\hline Brown-eyed susan & 0.0 & 0.0 & 0.0 & 0.0 & 0.0 & 0.0 & 0.0 & 0.0 & 0.1 & 4.0 \\
\hline Dandelion & 0.0 & 0.0 & 0.0 & 0.0 & 0.0 & 0.0 & 0.0 & 0.0 & 0.7 & 28.0 \\
\hline Death camas & 0.0 & 0.0 & 0.0 & 0.0 & 0.0 & 0.0 & 0.1 & 4.0 & 2.0 & 38.0 \\
\hline Dwarf mountain fleabane & 0.0 & 0.0 & 0.0 & 0.0 & $\mathrm{~T}$ & 2.0 & 0.0 & 0.0 & 0.0 & 0.0 \\
\hline Early blue violet & 0.0 & 0.0 & 0.0 & 0.0 & 0.0 & 0.0 & 0.0 & 0.0 & 0.1 & 2.0 \\
\hline Goatsbeard & 0.0 & 0.0 & 0.0 & 0.0 & 0.0 & 0.0 & 0.0 & 0.0 & 0.6 & 4.0 \\
\hline Holboell's rockcress & 0.3 & 14.0 & 0.0 & 0.0 & 0.2 & 8.0 & 0.0 & 0.0 & 0.1 & 2.0 \\
\hline Large-fruited lomatium & 0.3 & 4.0 & $\mathrm{~T}$ & 2.0 & 0.4 & 4.0 & 0.0 & 0.0 & 0.0 & 0.0 \\
\hline Low pussytoes & 10.5 & 94.0 & $\mathrm{~T}$ & 2.0 & $\mathrm{~T}$ & 2.0 & 0.0 & 0.0 & 0.6 & 6.0 \\
\hline Nine-leaf lomatium & 0.0 & 0.0 & 0.0 & 0.0 & 0.0 & 0.0 & 0.1 & 2.0 & 0.1 & 4.0 \\
\hline Nodding onion & 0.6 & 4.0 & 0.0 & 0.0 & $\mathrm{~T}$ & 2.0 & 0.0 & 0.0 & 0.3 & 12.0 \\
\hline Old man's whiskers & 0.0 & 0.0 & 0.0 & 0.0 & $\mathrm{~T}$ & 2.0 & 0.0 & 0.0 & 0.0 & 0.0 \\
\hline Pacific anemone & 0.0 & 0.0 & 0.0 & 0.0 & 0.0 & 0.0 & 0.1 & 2.0 & 0.6 & 6.0 \\
\hline Prairie groundsel & 0.0 & 0.0 & 0.0 & 0.0 & 3.4 & 40.0 & 1.1 & 34.0 & 2.5 & 40.0 \\
\hline Rosy pussytoes & 0.0 & 0.0 & 6.0 & 30.0 & 7.6 & 54.0 & 2.6 & 34.0 & 8.3 & 48.0 \\
\hline Sagebrush mariposa lily & 0.0 & 0.0 & 0.0 & 0.0 & $\mathrm{~T}$ & 2.0 & 0.1 & 2.0 & 0.6 & 22.0 \\
\hline Shaggy fleabane & 0.7 & 8.0 & 0.0 & 0.0 & 0.2 & 6.0 & 0.0 & 0.0 & 0.0 & 0.0 \\
\hline Slender hawksbeard & 0.0 & 0.0 & 0.0 & 0.0 & $\mathrm{~T}$ & 8.0 & 0.0 & 0.0 & 0.9 & 8.0 \\
\hline Spiny phlox & 0.0 & 0.0 & 11.0 & 60.0 & 10.5 & 62.0 & 4.8 & 54.0 & 7.6 & 48.0 \\
\hline Sulphur buckwheat & 0.0 & 0.0 & 0.0 & 0.0 & 0.0 & 0.0 & 0.0 & 0.0 & 0.3 & 2.0 \\
\hline Thin-leaved owlclover & 0.0 & 0.0 & 0.0 & 0.0 & 0.1 & 4.0 & 0.0 & 0.0 & 0.0 & 0.0 \\
\hline Timber milkvetch & 0.0 & 0.0 & 0.0 & 0.0 & 1.9 & 26.0 & 0.2 & 0.8 & 2.2 & 18.0 \\
\hline Western yarrow & 0.1 & 2.0 & 0.0 & 0.0 & 2.9 & 46.0 & 0.6 & 22.0 & 4.3 & 34.0 \\
\hline Wyeth buckwheat & 0.0 & 0.0 & 0.0 & 0.0 & 0.0 & 0.0 & 0.1 & 2.0 & 0.0 & 0.0 \\
\hline Yellow buckwheat & 0.8 & 12.0 & 1.0 & 6.0 & 0.0 & 0.0 & 0.0 & 0.0 & 0.0 & 0.0 \\
\hline Yellow owlclover & 0.0 & 0.0 & 0.0 & 0.0 & 0.0 & 0.0 & 0.5 & 10.0 & 0.0 & 0.0 \\
\hline Other Forbs & 2.1 & & 1.0 & & 0.9 & & 1.1 & & 6.7 & \\
\hline Total Forbs & 15.4 & & 19.0 & & 28.1 & & 11.5 & & 39.2 & \\
\hline \multicolumn{11}{|l|}{ Trees and Shrubs } \\
\hline Bearberry & 0.0 & 0.0 & $\mathrm{~T}$ & 2.0 & 0.0 & 0.0 & 0.0 & 0.0 & 0.0 & 0.0 \\
\hline Ponderosa pine & 0.0 & 0.0 & 0.0 & 0.0 & 0.0 & 0.0 & 2.5 & 14.0 & 12.9 & 32.0 \\
\hline Total Trees/Shrubs & 0.0 & & $\mathrm{~T}$ & & 0.0 & & 2.5 & & 12.9 & \\
\hline
\end{tabular}

abundant associates in "climax" stands of Ponderosa pine. An additional 30 years of complete protection from all ungulate grazing and fire, however, has resulted in a plant community quite different than the conventional thinking of the $1970 \mathrm{~s}$. These changes underline the value of exclosures in demonstrating successional patterns on a site-specific basis, albeit under conditions that the exclosure has imposed on the plant community.

The existing plant community inside the Skookumchuck exclosure does not necessarily imply the most productive conditions, or the optimum plant community that management should strive for throughout the Ponderosa Pine Zone in the Trench. Changes in minimally disturbed habitats, however, should challenge our thinking with respect to successional pathways and the potential implications for management.

\section{What Can Photographs Tell Us?}

Considerable differences are apparent between the 1951 and 2001 photographs of plant communities in the exclosure. Changes in the plant community are illustrated by the dominance of low growing grasses and forbs in the 1951 photos, which have been largely replaced with rough fescue and Idaho fescue in 2001. Note the white rock in the foreground of Figure 1 and Figure 2. It demonstrates that considerably more vegetation and litter is present inside the exclosure in 2001 compared to 1951.

Ponderosa pine that occupied the site as pole-sized stems in 1951 are now mature trees (Figure 3,4) and recruitment is clearly visible by comparing the 1951 and 2001 photos (Figure 1 to 4). Ponderosa pine appears to be acquiring dominance in the exclosure and it is also encroaching on the adjacent grazed area.

A repeat air photo study that was conducted in 1998 


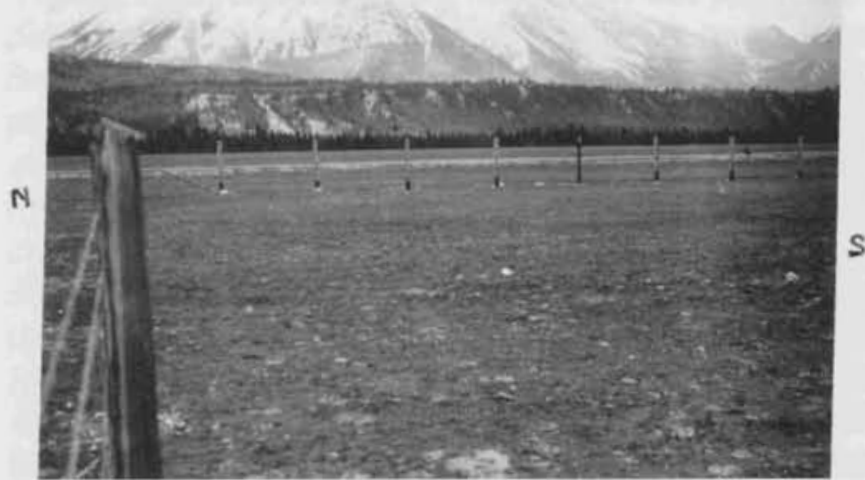

Figure 1. Skookumchuck Exclosure 1951. Looking east along the north fence.

confirmed that the conifer recruitment patterns observed in the exclosure are occurring at a landscape level in the Trench. Indeed, grassland and open forest have decreased by nearly $50 \%$ between 1958 and 1994 . If this rate of decline is applied to the entire Ponderosa Pine and Interior Douglas-fir biogeoclimatic zones in the
Trench, nearly 1500 ha of grassland and open forest could be lost annually. Consequently, ungulates will be confined to the remaining open areas, which ultimately will result in less forage for wildlife and domestic livestock, and deterioration in range condition.

\section{s Implications For Management}

Disturbance patterns in plant communities in the Rocky Mountain Trench have been complex over the long- and short-term history of the area. While certain disturbance patterns such as feral horses, pack trains, and lightening-caused fire have been removed or suppressed, a different set of influences now prevail on these communities. Presently, the most important influences are fire suppression, and the impacts of wildlife and cattle grazing. Interpretation of present grazing effects, however, needs to consider all factors that influence vegetation change including the residual effects of historical disturbances.

Numerous approaches for assessing range condition and plant succession in grazed communities have been developed over the last 50-60 years. Range condition, as described by E.J. Dyksterhuis in 1949, evaluates the effects of a single herbivore on plant community succes-

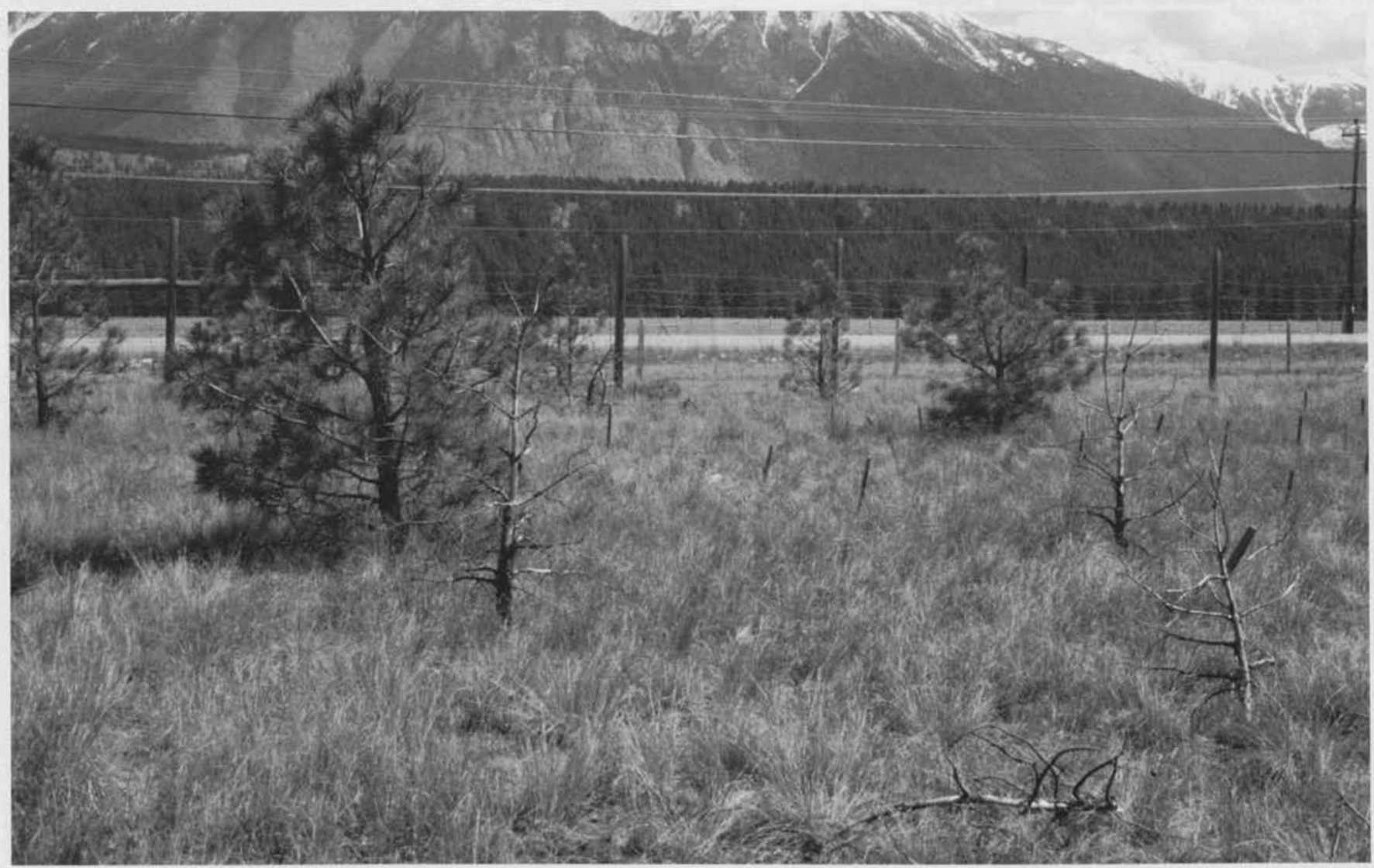

Figure 2. Skookumchuck Exclosure 2001. Looking east along the north fence. 
M

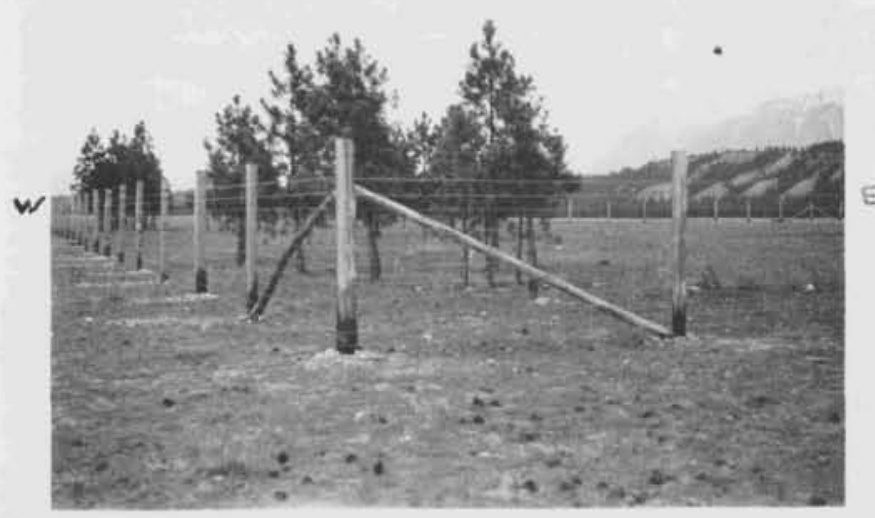

Figure 3. Skookumchuck Exclosure 1951. Looking northeast from the southwest corner.

sion resulting from variations in stocking levels, season of grazing, frequency of use, and intensity of defoliation on key species. This approach has limitations in interpreting the effects of multiple grazers on the same plant community, especially when wildlife populations and distribution patterns vary among years.
Deer, elk, and cattle often graze the same range pasture together, or sequentially throughout the year in the East Kootenay. Even though there is spatial overlap among the three ungulates, only about 12 forage species are eaten in common. Moreover, the species that are common in deer, elk and cattle diets are often grazed in different proportions, and at different times of the year. Consequently, the impacts of multiple grazers on the plant community will be different than for a single herbivore.

The "range condition" model may also have limited application on forested sites. For example, Dr. F. Hall stated in 1978 "Traditional range management concepts do not apply well to forested ecosystems because livestock is not the only factor affecting density and composition of vegetation". Higher successional stages on forest range do not necessarily result in higher range condition, especially as forest canopies close and plant communities respond to changes in light and soil moisture regimes.

Current ecological theories such as multiple steady states, discontinuous and irreversible transitions, and non-equilibrium communities appear relevant to the East Kootenay. The concept of multiple steady states is likely the most useful for predicting the effects of cattle grazing, wildlife grazing, and the impacts of fire or fire suppression.

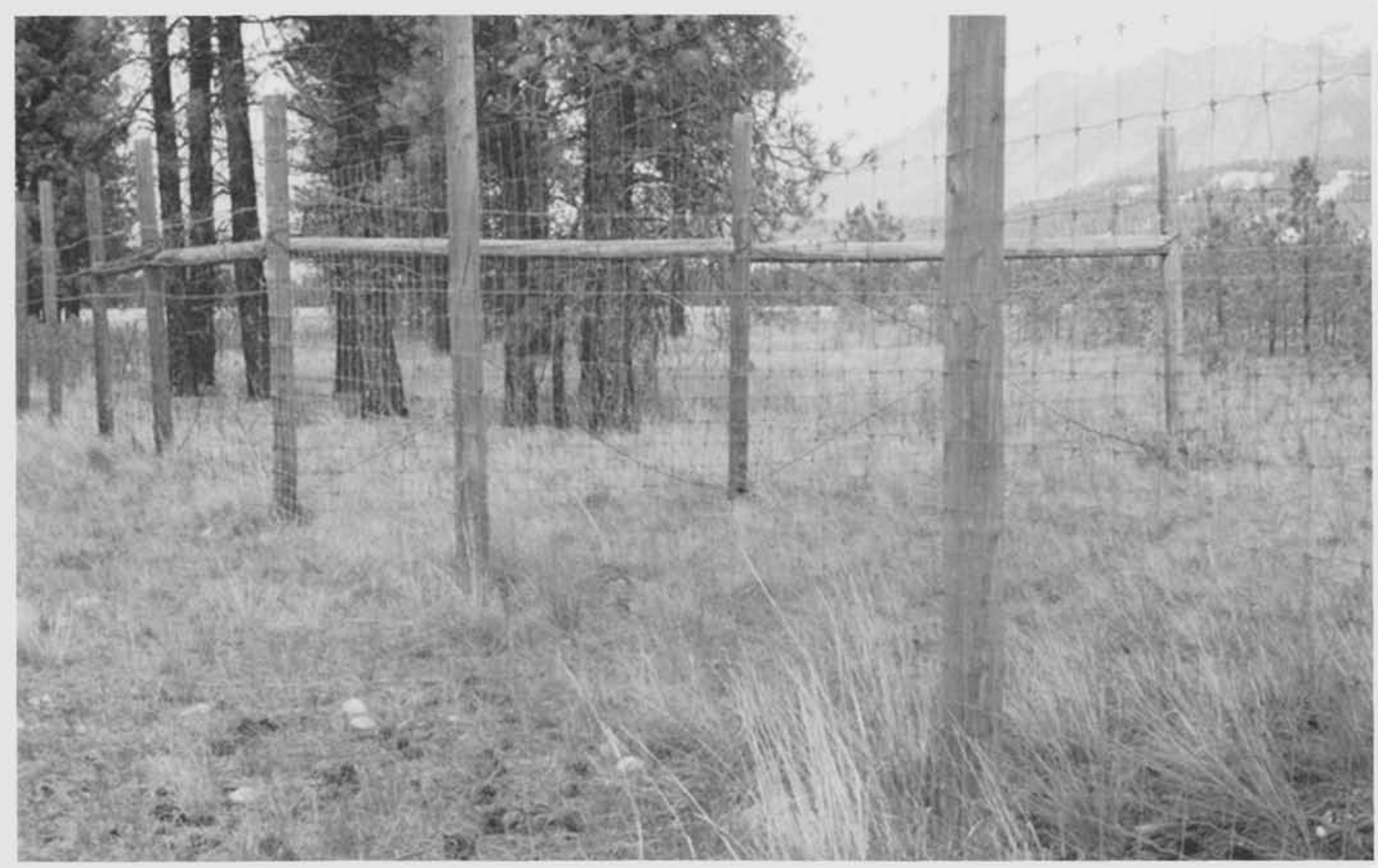

Figure 4. Skookumchuck Exclosure 2001. Looking northeast from the southwest corner. 
While various models have been proposed, the desired plant community (DPC) approach, developed by the Society for Range Management Task Group in 1995, provides a practical format for assessing vegetation goals and range trend relevant to management objectives. The DPC is based primarily on human values (including economic and social factors) rather than a concept of "climax" conditions that may have occurred in the past and are not achievable now. Despite the human focus, this approach does not exclude conservation issues, sustainability of resources, and ecological values. Indeed, these considerations should be the foundation for defining desired plant communities.

Regardless of the concept used, ecological principles and processes are of paramount importance in defining desired plant communities, as are current social values and management priorities. Integrated resource management recognizes different sites have different capabilities and multiple-use does not need to occur on every site. Management of public land, however, must be a blend of optimizing social values for products from the land base with environmental responsibility to maintain all values for future generations.

About the authors: Ross is a certified range consultant, Ross Range and Reclamation Services, P.O. Box 283, Cranbrook, BC, Canada, VIC 4H8; Wikeem is a natural resource consultant, Solterra Resources Inc., 4611 Westsyde Road, Kamloops, B.C., Canada, V2B 8N3. At the time of research, Wikeem was Range Scientist, Research Branch, BC Ministry of Forests, Kamloops, B.C. and. Ross was Range Ecologist, Research Branch, BC Ministry of Forests, Cranbrook, B.C.
This project was supported by the Sustainable Environment Fund, the Forest Resources Development Agreement, the Beef Cattle Industry Development Fund and the Kootenay/Boundary Grazing Enhancement Program.

\section{References and Other Reading}

Borman, M. M. and D.A. Pyke. 1994. Successional theory and the desired plant community approach. Rangelands 16(2):82-84.

BraumandI, T.F. and M.P. Curran. 1992. A field guide for site identification and interpretation for the Nelson Forest Region. BC Min. Forests, Nelson, B.C.

Daubenmire, R.F. 1959. A canopy-coverage method of vegetation analysis. Northw. Sci. 33: 43-64.

Friedel, M.H. 1991. Range condition assessment and the concept of threshold - a viewpoint. J. Range Manage. 42:422-426.

Hall, F.C. 1978. Applicability of rangeland management concepts to forest-range in the Pacific Northwest. Intern. Rangeland Cong. Proc. 1:496-499.

Laycock, W.A. 1991. Stable states and thresholds of range condition on North American rangelands: A viewpoint. J. Range Manage. 44(5):427-433.

McLean, A., and E.W. Tisdale. 1972. Recovery rate of depleted range sites under protection from grazing. J. Range Manage. 25:178-181.

Pitt, M.D. 1982. East Kootenay problem analysis. Interactions among grass, trees, elk and cattle. B.C. Minist. For. 65p.

Smyth, F.J. 1937. Tales of the Kootenays. J.J. Douglas Ltd. Vancouver, B.C.

Society for Range Management Task Group on Unity in Concept and Terminology. 1995. New concepts for assessment of rangeland condition. J. Range Manage. 48:271-282.

Tisdale, E. W. 1950. Grazing of forest lands in Interior British Columbia. J. Forestry 48:856-860.

Westoby, M., B. Walker, and I. Noy-Meir. 1989. Opportunistic management for rangelands not at equilibrium. J. Range Manage. $42: 266-274$. 